\title{
Mesenchymal stem/stromal cell function in modulating cell death
}

\author{
Abderrahim Naji ${ }^{1 *}$ (D, Benoit Favier ${ }^{2}$, Frédéric Deschaseaux ${ }^{3}$, Nathalie Rouas-Freiss ${ }^{4}$, Masamitsu Eitoku ${ }^{1}$ and \\ Narufumi Suganuma ${ }^{1 *}$
}

\begin{abstract}
Mesenchymal stem/stromal cells (MSCs) delivered as cell therapy to individuals with degenerative and/or inflammatory disorders can help improve organ features and resolve inflammation, as demonstrated in preclinical studies and to some extent in clinical studies. MSCs have trophic, homing/migration, and immunosuppression functions, with many benefits in therapeutics. MSC functions are thought to depend on the paracrine action of soluble factors and/or the expression of membrane-bound molecules, mostly belonging to the molecular class of adhesion molecules, chemokines, enzymes, growth factors, and interleukins. Cutting-edge studies underline bioactive exchanges, including that of ions, nucleic acids, proteins, and organelles transferred from MSCs to stressed cells, thereby improving the cells' survival and function. From this aspect, MSC death modulation function appears as a decisive biological function that could carry a significant part of the therapeutic effects of MSCs. Identifying the function and modes of actions of MSCs in modulating cell death may be exploited to enhance consistency and efficiency of cell therapy that is based on MSCs as medical treatment for degenerative and/or inflammatory diseases. Here, we review the essentials of MSC functions in modulating cell death in unfit cells, and its modes of actions based on current advances and outline the clinical implications.
\end{abstract}

Keywords: Mesenchymal stem cell, Cell function, Cell death, Cell therapy

\section{Background}

Mesenchymal stem/stromal cells (MSCs) are isolated from different biological sources and expanded ex vivo in culture. These MSC cultures are thought to contain diverse cell subsets resulting from intrinsic and extrinsic influences in addition to inherent disparities related to sources and donors [1-5]. The MSC identity is under scrutiny [6], despite a consensus for the minimum criteria to identify MSCs proposed a decade ago by the International Committee for Cell Therapy (ISCT) [7]: (1) MSCs must be adherent and proliferate in vitro under standard culture conditions; (2) MSCs must feature surface expression of cluster of differentiation (CD)105, 73, and 90 but not CD45, 34, 14, 11b, 79 $\alpha$, and 19, or human leucocyte antigen-DR; and (3) MSCs must, upon suitable stimulation in vitro, demonstrate an ability to

\footnotetext{
*Correspondence: najiab@kochi-u.ac.jp; nsuganuma@kochi-u.ac.jp ${ }^{1}$ Department of Environmental Medicine, Cooperative Medicine Unit, Research and Education Faculty, Medicine Science Cluster, Kochi Medical School (KMS), Kochi University, Kohasu, Oko-Cho, Nankoku City, Kochi Prefecture 783-8505, Japan

Full list of author information is available at the end of the article
}

differentiate into adipocytes, chondroblasts, and osteoblasts. Since then, the ISCT criteria have been used to assess the MSC identity in preclinical and clinical studies but often because of lack of alternative methods for identifying MSCs per se with explicit biomarkers [6, 810]. However, both scientists and clinicians alike acknowledge that cell heterogeneity is to be expected in any ex vivo MSC cultures used in preclinical and clinical settings [2, 4, 5, 11-14]. MSCs from different biological sources (i.e., from the bone marrow [BM-MSCs], adipose tissue [ASCs], or umbilical cord [UC-MSCs]), a fortiori are not alike, but these MSCs in ex vivo cultures might share common features in agreement with the ISCT criteria $[5,15]$.

The identification of unambiguous biomarkers to select identical MSCs regardless of source, donor, or any other variables is critical to develop MSC therapy [6]. Therefore, investigations of MSC identity remain crucial in the search for specific biomarkers to define MSC identity in vivo and ex vivo. Several works have attempted to sort MSCs with the use of "stemness" biomarkers by targeting surface 
antigens such as STRO-1, stage-specific embryonic antigen 1 (SSEA-1), SSEA-4, CD271, or CD146 [6]. Still, no marker has shown a unique specificity for identifying MSCs per se $[6,16]$.

Despite these hurdles in coining MSC identity, knowledge of MSC functions is advancing rapidly, conveying other means to assess MSCs in vitro according to their actual biological functions, which can also predict the therapeutic potency of MSCs in vivo [8, 9, 17, 18]. Usually, ex vivo-expanded MSCs are considered to exhibit five biological functions of interest in therapy [7, 19-27]: (1) proliferation, (2) multipotency, (3) homing/migration, (4) trophic ability, and (5) immunosuppression, often examined independent of each other. Scientific advances have provided further understanding of modes of actions of each MSC function [1, 19, 25, 27-30]. Yet, MSC functions remain incompletely defined because of the complexity and diversity in regulation and/or modes of actions of each MSC function considered individually as well as overlaps in biological effects [17, 27, 31, 32].

Here, we discuss a sixth function of MSCs-death modulation. We focus predominately on the death modulation function of MSCs obtained from different species and biological sources, its modes of actions, and its clinical implications for human MSCs to be exploited for degenerative and/or inflammatory diseases [33, 34].

\section{Regulated cell death in diseases}

Regulated cell death (RCD) is a fundamental biological process controlling cell fate in health and diseases [3335]. RCD largely consists of apoptosis, necroptosis, and pyroptosis, among the most deciphered cell death modes [36]. Apoptosis represents an RCD whose execution depends on caspases-3/6/7, whereas mixed lineage kinase domain-like and gasdermin D proteins execute necroptosis and pyroptosis, respectively [36]. Uncontrolled RCD in diseases amplifies tissue damage and inflammation, which in turn could result in permanently impaired organ functions [33]. Hence, RCD is often engaged in undesirable events prolonging degenerative and/or inflammatory diseases [33]. However, cells that are resistant to RCD might participate in tumor growth [37]. In both cases, RCD pathways represent relevant therapeutic targets for numerous disorders.

\section{Biological function of MSCs in modulating cell death}

Recently, an increasing number of studies have emphasized the ability of MSCs to promote cell rescue or cell survival of injured adult stem cells or somatic cells, enduring early signaling of RCD, via multifaceted modes of actions both in vitro and in vivo [38-60]. MSC functioning to modulate processes of RCD could directly aid in restraining damage caused to organs in diseases and/or indirectly restraining the release of harmful factors by dying cells, thereby avoiding the amplification of deleterious inflammation, additional tissue damage, and loss of organ function [33]. The death modulation function of MSCs should be considered separately from their trophic function or immunosuppression function, because the modes of actions may be independent, although the biological effects might be intertwined [17].

Actually, evidence shows that MSCs modulate RCD occurring in third-party cells, especially those affected by apoptosis, necroptosis, and pyroptosis $[17,39,41$, $46-48,50,53,54,56,57,61,62]$. The MSC death modulation function has been rarely identified as such, and conceivably, this function is confused with the MSC trophic function or immunosuppression function because of overlap in biological effects that can be individually attributed to each of these functions [17]. Accordingly, several preclinical studies indicated that MSCs are susceptible to cellular interactions with adult stem cells, progenitors, or somatic cells, such as hematopoietic stem cells (HSCs) or cardiomyoblasts, alveolar epithelial cells, cardiomyocytes, endothelial cells, macrophages, and neurons, favoring cell survival [39, 41, $46-48,50,53,54,56,57,61,62]$. Here, we discuss the modes of actions that mediate the MSC death modulation function.

\section{Modes of actions of MSC death modulation function}

The MSC death modulation function can be envisaged via different elaborated modes of actions that could involve (1) secreted paracrine factors $[39,42,45,47,48$, $50,54-58,61,63-65]$ (Table 1), most likely $(2) \mathrm{Ca}^{2+}$ ion exchange via the connexin (Cx)-43 gap junction [41, 43, 60, 66-68] (Table 2), (3) transfer of mitochondria via tunneling nanotubes (TNTs) [27, 38, 41, 43, 44, 46, 69] (Table 3), and (4) transfer of bioactive microRNAs (miRNAs) and/or proteins via extracellular vesicles (EVs) [27, 40, 43, 46, 51, 53, 62, 70-73] (Table 4) from MSCs to RCD-affected cells. However, it should be noted that modes of actions of MSCs in modulating cell death of unfit cells that encompass secretion of paracrine factors and/or other pathways remain uncertain (Table 1). By contrast, modes of actions depending on gap junctions, TNTs, and EVs appear dedicated specifically to rescue cells from death pathways. Thereby, we evoke paracrine factors and/or other pathways in MSC death modulation function, but we focus explicitly on modes of actions implying intercellular communications such as gap junctions, TNTs, and EVs between MSCs and unfit cells.

\section{Secreted paracrine factors}

There are numerous and solid evidences supporting the role of paracrine factors secreted by MSCs in ameliorating conditions in degenerative and/or inflammatory diseases both in preclinical and clinical settings [23-25, 
Table 1 Mesenchymal stem/stromal cell (MSC) death modulation function depending on paracrine factors and/or other modes of actions

\begin{tabular}{|c|c|c|c|c|}
\hline Studies & Sources of MSCS & MSC death modulation function & Modes of actions & References \\
\hline $\begin{array}{l}\text { Preclinical in vitro } \\
\text { and in vivo }\end{array}$ & Human BM-MSCs & $\begin{array}{l}\text { Apoptosis in human primary CD34+ cells induced by } \\
\text {-irradiation with xenotransplantation in a baboon model }\end{array}$ & Not determined & Drouet et al. [42] \\
\hline Preclinical in vitro & Human BM-MSCs & $\begin{array}{l}\text { Activation-induced cell death, apoptosis induced by } \\
\text { anti-CD3 Abs, or deprivation of serum or anti-Fas Abs } \\
\text { in primary human thymocytes and human Jurkat T cell } \\
\text { line }\end{array}$ & Fas-FasL pathway inhibition & Benvenuto et al. [39] \\
\hline Preclinical in vitro & Human BM-MSCs & $\begin{array}{l}\text { Apoptosis in human primary neutrophils induced by IL-8, } \\
\text { or in resting state }\end{array}$ & IL-6, STAT3 & Raffaghello et al. [58] \\
\hline Preclinical in vitro & Rat BM-MSCs & $\begin{array}{l}\text { Apoptosis in Rat PC12 neuron cell line and rat primary } \\
\text { cortical neurons induced by deprivation of serum and } \\
\text { exposure to EtOH }\end{array}$ & PI3K/Akt, ERK1/2 & Liu et al. [45] \\
\hline Preclinical in vitro & $\begin{array}{l}\text { Mouse and human } \\
\text { BM-MSCs }\end{array}$ & $\begin{array}{l}\text { Apoptosis and/or necroptosis induced in rat PC12 } \\
\text { neuron cell line, human ReNcell CX neural progenitor } \\
\text { cell line, and rat cortical primary neurons induced by } \\
6-\mathrm{OHDA}\end{array}$ & Prosaposin & Li et al. [65] \\
\hline Preclinical in vitro & Human UC-MSCs & $\begin{array}{l}\text { Apoptosis in human primary neutrophils induced by } \\
\text { deprivation of serum }\end{array}$ & Not determined & Maqbool et al. [47] \\
\hline Preclinical in vitro & Rat BM-MSCs & $\begin{array}{l}\text { Apoptosis in human SH-SY5Y neuroblastoma cell line } \\
\text { induced by misfolded tau protein }\end{array}$ & Not determined & Zilka et al. [56] \\
\hline Preclinical in vitro & $\begin{array}{l}\text { Mouse and human } \\
\text { BM-MSCs }\end{array}$ & $\begin{array}{l}\text { Apoptosis in rat primary cortical neurons induced by } \\
\text { deprivation of glucose and oxygen }\end{array}$ & PI3K/Akt, STAT3 & Scheibe et al. [50] \\
\hline Preclinical in vivo & Rat BMMSCs & $\begin{array}{l}\text { Apoptosis in rat lung fibroblasts induced by cigarette } \\
\text { smoke extract }\end{array}$ & $\begin{array}{l}\text { PI3K/Akt and Caspase-3 } \\
\text { inhibition }\end{array}$ & Kim et al. [64] \\
\hline $\begin{array}{l}\text { Preclinical in vitro } \\
\text { and in vivo }\end{array}$ & Rat BM-MSCs & $\begin{array}{l}\text { Apoptosis in rat INS-1 pancreatic cell line induced by } \\
\text { high glucose exposure and in pancreatic } \beta \text { cells in STZ } \\
\text { induced type } 2 \text { DM in Rat }\end{array}$ & Not determined & Zhao et al. [54] \\
\hline Clinical & Human BM-MSCs & $\begin{array}{l}\text { Apoptosis and necrosis in alveolar epithelial cells in } \\
\text { patients with ARDS }\end{array}$ & $\begin{array}{l}\text { Immunosuppressive and/or } \\
\text { trophic factors and/or EVs }\end{array}$ & Simonson et al. [63] \\
\hline Preclinical in vitro & Human BM-MSCs & $\begin{array}{l}\text { Pyroptosis in human THP-1 monocytic cell line and } \\
\text { mouse MH-S alveolar macrophage cell line induced by } \\
\text { nanoparticles }\end{array}$ & $\mid \mathrm{LL}-10$ & Naji et al. [48] \\
\hline Preclinical in vitro & Rat BM-MSCs & $\begin{array}{l}\text { Apoptosis and necroptosis in mouse primary cortical } \\
\text { neurons induced by deprivation of glucose and oxygen }\end{array}$ & $\begin{array}{l}\text { Caspase- } 3 \text { and RIP-1/3 } \\
\text { inhibition }\end{array}$ & Kong et al. [57] \\
\hline Preclinical in vivo & Mouse BM-MSCs & $\begin{array}{l}\text { Pyroptosis in mouse hepatocyte induced by D-galactosamine } \\
\text { acute liver injury in a mouse model }\end{array}$ & IL-10 & Wang et al. [61] \\
\hline $\begin{array}{l}\text { Preclinical in vitro } \\
\text { and in vivo }\end{array}$ & Rat BM-MSCs & $\begin{array}{l}\text { Apoptosis in rat primary cortical neurons induced by } \\
\text { deprivation of glucose and oxygen and in rat cortical } \\
\text { neurons induced by ischemia with right carotid artery } \\
\text { ligation and exposure to hypoxia in a rat model }\end{array}$ & BDNF, mTOR & Zheng et al. [55] \\
\hline
\end{tabular}

74-76]. Paracrine factors secreted by MSCs, including chemokines, cytokines, and growth factors, influence the progress of endogenous progenitors' differentiation such as for angiogenesis or neurogenesis and affect the course of an immune response [25, 74, 76, 77]. All these biological effects may indirectly modulate overall cell death by improving cell survival and/or cell renewal in damaged or diseased tissues $[17,75]$. Yet, MSC death modulation function must be considered separately from MSC trophic function and immunosuppression function, as MSC death modulation function would rather have a direct action on death pathways occurring in unfit cells
[17]. Hence, paracrine factors secreted by MSCs might participate to MSC death modulation function (Table 1) in different cells subjected to different conditions of RCD. This has been shown mostly in preclinical studies in vitro and in vivo, especially for IL-6 and IL-10 cytokines [48, 58, 61] and brain-derived neurotrophic factor (BDNF) growth factor [55]. Of note, in a preclinical study in vitro, MSCs prevent RCD such as apoptosis of human resting neutrophils and neutrophils stimulated with IL-8 [58]. In this case, MSC death modulation function did not require cell-to-cell contact with unfit neutrophils to rescue cells from apoptosis [58]. The paracrine factor secreted by 
Table 2 Mesenchymal stem/stromal cell (MSC) death modulation function depending on gap junctions

\begin{tabular}{|c|c|c|c|c|}
\hline Studies & Sources of MSCs & MSC death modulation function & Modes of actions & References \\
\hline Preclinical in vitro & Mouse BM-MSCs & $\begin{array}{l}\text { Apoptosis in rat } \mathrm{H} 9 \mathrm{C} 2 \text { cardiomyoblast cell line induced } \\
\text { by deprivation of glucose and oxygen }\end{array}$ & CXs and/or TNTs & Cselenyak [41] \\
\hline $\begin{array}{l}\text { Preclinical in vitro } \\
\text { and in vivo }\end{array}$ & Rat BM-MSCs & $\begin{array}{l}\text { Apoptosis in rat MSCs induced by deprivation of oxygen } \\
\text { and in mouse cardiomyocytes in a myocardial infarction } \\
\text { mouse model induced by LAD artery ligation }\end{array}$ & $C x-43$ & Wang et al. [67] \\
\hline $\begin{array}{l}\text { Preclinical in vitro } \\
\text { and in vivo }\end{array}$ & $\begin{array}{l}\text { Mouse and human } \\
\text { BM-MSCs }\end{array}$ & $\begin{array}{l}\text { Apoptosis in human and mouse primary CD } 34+\text { cells in } \\
\text { vitro, and in vivo in a mouse model of bone marrow } \\
\text { transplantation }\end{array}$ & $C x-43, C x-45, C X C L 12$ & Schajnovitz et al. [60] \\
\hline Preclinical in vivo & $\begin{array}{l}\text { Mouse and human } \\
\text { BM-MSCs }\end{array}$ & $\begin{array}{l}\text { Apoptosis in alveolar epithelial cells induced by LPS in } \\
\text { vivo in an acute lung injury mouse model }\end{array}$ & $\begin{array}{l}\text { Cx- } 43 \text {, transfer of } \\
\text { mitochondria via EVs } \\
\text { and TNTs }\end{array}$ & Islam et al. [43] \\
\hline Preclinical in vitro & Human BM-MSCs & $\begin{array}{l}\text { Apoptosis in human MM cell lines RPMI 8266, U266, XG-4, } \\
\text { XG-7, and human primary MM cells }\end{array}$ & $C x-43$ & Zhang et al. [68] \\
\hline Preclinical in vitro & Human BM-MSCs & $\begin{array}{l}\text { Apoptosis and/or necroptosis in human MM cell line } \\
\text { RPMI } 8266, \text { U266, XG-7, and human primary MM cells } \\
\text { induced by bortezomib }\end{array}$ & $C x-43$ & Fu et al. [66] \\
\hline
\end{tabular}

This table is representative but not exhaustive. Although the table recapitulates studies on MSC death modulation function depending on gap junctions, this does not exclude the implication of other modes of actions. Studies are ordered from the oldest to the most recent. BM-MSCs, bone marrow mesenchymal stem/ stromal cells; CXs, connexins; CXCL, CXC ligand; TNTs, tunneling nanotubes; LAD, left anterior descending; LPS, lipopolysaccharide; EVs, extracellular vesicles; MM, multiple myeloma

MSCs that were responsible for neutrophil protection from apoptosis appeared to be IL- 6 and involved signaling via the activation of STAT-3 transcription factor [58]. Similarly, IL-10 secreted by MSCs were found to be implicated in the inhibition of RCD, such as pyroptosis in human and mouse macrophages induced by nanoparticles in vitro [48], and of pyroptosis in mouse hepatocytes induced by D-galactosamine in vivo [61]. Furthermore, RCD occurring in rat cortical neurons following hypoxia-ischemia in vitro were prevented when in co-culture with MSCs [55]. As well, in vivo experiments in a rat ischemia model showed that MSC adoptive transfer significantly reduced brain damage [55]. BDNF was identified as a paracrine factor secreted by MSCs responsible for MSC death

Table 3 Mesenchymal stem/stromal cell (MSC) death modulation function depending on tunneling nanotubes

\begin{tabular}{|c|c|c|c|c|}
\hline Studies & Sources of MSCs & MSC death modulation function & Modes of actions & References \\
\hline Preclinical in vitro & Human BM-MSCs & $\begin{array}{l}\text { Apoptosis in human lung epithelial cell lines A549p } \\
\text { induced by ethidium bromide }\end{array}$ & $\begin{array}{l}\text { Transfer of mitochondria via } \\
\text { EVs and TNTs or both }\end{array}$ & Spees et al. [27] \\
\hline Preclinical in vitro & Mouse BM-MSCs & $\begin{array}{l}\text { Apoptosis in rat } \mathrm{H} 9 \mathrm{c} 2 \text { cardiomyoblast cell line induced } \\
\text { by deprivation of glucose and oxygen }\end{array}$ & Cxs and/or TNTs & Cselenyak [41] \\
\hline Preclinical in vivo & $\begin{array}{l}\text { Mouse and human } \\
\text { BM-MSCs }\end{array}$ & $\begin{array}{l}\text { Apoptosis in alveolar epithelial cells induced by LPS } \\
\text { in vivo in an acute lung injury mouse model }\end{array}$ & $\begin{array}{l}\text { Cx-43, transfer of mitochondria } \\
\text { via EVs and TNTs }\end{array}$ & Islam et al. [43] \\
\hline Preclinical in vitro & Human BM-MSCs & $\begin{array}{l}\text { Apoptosis in human primary HUVEC induced by } \\
\text { deprivation of oxygen }\end{array}$ & $\begin{array}{l}\text { Transfer of mitochondria via } \\
\text { TNTs }\end{array}$ & Liu et al. [44] \\
\hline $\begin{array}{l}\text { Preclinical in vitro } \\
\text { and in vivo }\end{array}$ & Human BM-MSCs & $\begin{array}{l}\text { Apoptosis in human primary bronchial epithelial } \\
\text { cells and bronchial smooth muscle cells and human } \\
\text { epithelial cell line BEAS-2B, A549 induced by rotenone. } \\
\text { Apoptosis in mouse primary tracheal epithelial cells } \\
\text { and mouse lung epithelial cell lines ML-12 and lung } \\
\text { adenocarcinoma LA-4 induced by rotenone. } \\
\text { Apoptosis in alveolar epithelial cells in lung injury } \\
\text { mouse models induced by rotenone or an allergen }\end{array}$ & $\begin{array}{l}\text { Transfer of mitochondria via } \\
\text { TNTs }\end{array}$ & Ahmad et al. [38] \\
\hline Preclinical in vitro & Rat BM-MSCs & $\begin{array}{l}\text { Apoptosis in rat cardiomyoblast cell line } \mathrm{H} 9 \mathrm{c} 2 \text { induced } \\
\text { by deprivation of glucose and oxygen }\end{array}$ & $\begin{array}{l}\text { Transfer of mitochondria via } \\
\text { TNTs }\end{array}$ & Han et al. [69] \\
\hline $\begin{array}{l}\text { Preclinical in vitro } \\
\text { and in vivo }\end{array}$ & Human ASCs & $\begin{array}{l}\text { Apoptosis in human primary cardiomyocytes or } \\
\text { endothelial cells induced by ethidium bromide, } \\
\text { hydrogen peroxide, or doxorubicin. Apoptosis in } \\
\text { mouse cardiomyocytes induced in a myocardial } \\
\text { infarction mouse model with LAD artery ligation }\end{array}$ & $\begin{array}{l}\text { Transfer of mitochondria via } \\
\text { EVs and/or TNTs, and Heme } \\
\text { oxygenase }\end{array}$ & $\begin{array}{l}\text { Mahrouf-Yorgov } \\
\text { et al. [46] }\end{array}$ \\
\hline
\end{tabular}

This table is representative but not exhaustive. Although the table recapitulates studies on MSC death modulation function depending on tunneling nanotubes, this does not exclude the implication of other modes of actions. Studies are ordered from the oldest to the most recent. BM-MSCs, bone marrow mesenchymal stem/stromal cells; ASCs, adipose tissue mesenchymal stem/stromal cells; EVs, extracellular vesicles; TNTs, tunneling nanotubes; CXs, connexins; LPS, lipopolysaccharide; HUVEC, human umbilical vein endothelial cells; $L A D$, left anterior descending 
Table 4 Mesenchymal stem/stromal cell (MSC) death modulation function depending on extracellular vesicles

\begin{tabular}{|c|c|c|c|c|}
\hline Studies & Sources of MSCs & MSC death modulation function & Modes of actions & References \\
\hline Preclinical in vitro & Human BM-MSCs & $\begin{array}{l}\text { Apoptosis in human } \mathrm{A} 549 \rho^{\circ} \text { lung epithelial } \\
\text { cell line induced by ethidium bromide }\end{array}$ & $\begin{array}{l}\text { Transfer of mitochondria } \\
\text { via EVs or TNTs or both }\end{array}$ & Spees et al. [27] \\
\hline Preclinical in vivo & $\begin{array}{l}\text { Mouse and human } \\
\text { BM-MSCs }\end{array}$ & $\begin{array}{l}\text { Apoptosis in alveolar epithelial cells induced } \\
\text { by LPS in vivo in an acute lung injury mouse } \\
\text { model }\end{array}$ & $\begin{array}{l}\text { Cx-43, transfer of } \\
\text { mitochondria via EVs and } \\
\text { TNTs }\end{array}$ & Islam et al. [43] \\
\hline $\begin{array}{l}\text { Preclinical in vitro } \\
\text { and in vivo }\end{array}$ & Human BM-MSCs & $\begin{array}{l}\text { Apoptosis in human MCF-7 breast cancer } \\
\text { cell line and human KHOS osteosarcoma } \\
\text { cell line induced by deprivation of serum. } \\
\text { Apoptosis in vivo in MCF-7 inoculated in a } \\
\text { NU/NU mouse model }\end{array}$ & $\begin{array}{l}\text { Transfer of miRNA-21 and } \\
\text { miRNA-34a via EVs }\end{array}$ & $\begin{array}{l}\text { Vallabhaneni } \\
\text { et al. [72] }\end{array}$ \\
\hline $\begin{array}{l}\text { Preclinical in vitro } \\
\text { and in vivo }\end{array}$ & Human BM-MSCs & $\begin{array}{l}\text { Apoptosis in human primary MSCs and in } \\
\text { mouse RAW } 264.7 \text { macrophage cell line } \\
\text { induced by oxidative stress and/or silica } \\
\text { particles in vitro and in vivo in a mouse } \\
\text { silicosis model }\end{array}$ & $\begin{array}{l}\text { Transfer of mitochondria } \\
\text { and miRNA-451 via EVs }\end{array}$ & Phinney et al. [73] \\
\hline Preclinical in vivo & Human UC-MSCs & $\begin{array}{l}\text { Apoptosis in human HFL1 lung fibroblast, } \\
\text { HaCAT keratinocyte cell line, and rat primary } \\
\text { dermal fibroblasts induced by heat stress in } \\
\text { vitro. Apoptosis in rat skin epithelial cells in } \\
\text { vivo in a rat burn model }\end{array}$ & Transfer of Wnt4 via EVs & Zhang et al. [93] \\
\hline $\begin{array}{l}\text { Preclinical in vitro } \\
\text { and in vivo }\end{array}$ & $\begin{array}{l}\text { Mouse and human } \\
\text { BM-MSCs }\end{array}$ & $\begin{array}{l}\text { Apoptosis in mouse primary bone marrow } \\
\text { cells and mouse FDC-P1 hematopoietic cell } \\
\text { line induced by } \gamma \text {-irradiation with } \\
\text { xenotransplantation in a mouse model }\end{array}$ & $\begin{array}{l}\text { Transfer of miRNA-210-5p, } \\
\text { miRNA-106b-3p, and } \\
\text { miRNA-155-5p via EVs }\end{array}$ & Wen et al. [51] \\
\hline Clinical & Human BM-MSCs & $\begin{array}{l}\text { Apoptosis and necrosis in alveolar epithelial } \\
\text { cells in patients with ARDS }\end{array}$ & $\begin{array}{l}\text { Immunosuppressive } \\
\text { and/or trophic factors } \\
\text { and/or EVs }\end{array}$ & $\begin{array}{l}\text { Simonson } \\
\text { et al. [63] }\end{array}$ \\
\hline $\begin{array}{l}\text { Preclinical in vitro } \\
\text { and in vivo }\end{array}$ & Human ASCs & $\begin{array}{l}\text { Apoptosis in human primary cardiomyocytes } \\
\text { or endothelial cells induced by ethidium } \\
\text { bromide, hydrogen peroxide, or doxorubicin. } \\
\text { Apoptosis in mouse cardiomyocytes induced } \\
\text { in a myocardial infarction mouse model with } \\
\text { LAD artery ligation }\end{array}$ & $\begin{array}{l}\text { Transfer of mitochondria } \\
\text { via EVs and/or TNTs, and } \\
\text { Heme oxygenase }\end{array}$ & $\begin{array}{l}\text { Mahrouf-Yorgov } \\
\text { et al. [46] }\end{array}$ \\
\hline Preclinical in vitro & Human BM-MSCs & $\begin{array}{l}\text { Apoptosis and necroptosis human primary } \\
\text { B cell chronic lymphocytic leukemia induced } \\
\text { by bortezomib, cladribine, fludarabine, } \\
\text { flavopiridol, or methylprednisolone (others) }\end{array}$ & EVs & Crompot et al. [40] \\
\hline $\begin{array}{l}\text { Preclinical in vitro } \\
\text { and in vivo }\end{array}$ & Human UC-MSCs & $\begin{array}{l}\text { Apoptosis in Human L02 hepatocyte cell line } \\
\text { induced by hydrogen peroxide or carbon } \\
\text { tetrachloride. Apoptosis induced in mouse } \\
\text { hepatocyte in vivo by carbon tetrachloride in } \\
\text { NU/NU mouse model }\end{array}$ & Transfer of GPX1 via EVs & Yan et al. [92] \\
\hline $\begin{array}{l}\text { Preclinical in vitro } \\
\text { and in vivo }\end{array}$ & Human iPSC-MSCs & $\begin{array}{l}\text { Necroptosis in Human HK-2 epithelial cell } \\
\text { line induced by deprivation of oxygen. } \\
\text { Necroptosis in renal rat epithelial cells } \\
\text { induced in vivo by clamping of renal } \\
\text { pedicles in an acute kidney injury rat model }\end{array}$ & Transfer of SP1 via EVs & Yuan et al. [53] \\
\hline $\begin{array}{l}\text { Preclinical in vitro } \\
\text { and in vivo }\end{array}$ & Mouse BM-MSCs & $\begin{array}{l}\text { Apoptosis in mouse primary cardiomyocytes } \\
\text { induced by deprivation of oxygen and serum. } \\
\text { Apoptosis in mouse cardiomyocytes in vivo } \\
\text { in a myocardial infarction mouse model } \\
\text { induced by LAD artery ligation }\end{array}$ & $\begin{array}{l}\text { Transfer of miRNA-125b } \\
\text { via EVs }\end{array}$ & Xiao et al. [62] \\
\hline Preclinical in vitro & Human WJ-MSCS & $\begin{array}{l}\text { Apoptosis in mouse Neuro2a neuroblastoma } \\
\text { cell line induced by deprivation of glucose } \\
\text { and oxygen }\end{array}$ & $\begin{array}{l}\text { Transfer of miRNA let-7a, } \\
\text { let-7e, and let-7-5p via } \\
\text { EVs }\end{array}$ & $\begin{array}{l}\text { Joerger-Messerli } \\
\text { et al. [71] }\end{array}$ \\
\hline $\begin{array}{l}\text { Preclinical in vitro } \\
\text { and in vivo }\end{array}$ & Human UC-MSCs & $\begin{array}{l}\text { Apoptosis in human H1299 and PC-9 lung } \\
\text { adenocarcinoma cell lines induced by } \\
\text { deprivation of serum. Apoptosis in vivo in } \\
\text { human lung H1299 adenocarcinoma cell line } \\
\text { in vivo after xenotransplantation in a NU/NU } \\
\text { mouse model }\end{array}$ & $\begin{array}{l}\text { Transfer of miRNA-410a } \\
\text { via EVs }\end{array}$ & Dong et al. [70] \\
\hline
\end{tabular}

This table is representative but not exhaustive. Although the table recapitulates studies on MSC death modulation function depending on extracellular vesicles, this does not exclude the implication of other modes of actions. Studies are ordered from the oldest to the most recent. BM-MSCs, bone marrow mesenchymal stem/stromal cells; ASCs, adipose tissue mesenchymal stem/stromal cells; iPSC-MSCs, inducible pluripotent stem/stromal cell mesenchymal stem cells; WJ-MSCs, Wharton's jelly mesenchymal stem/stromal cells; UC-MSCs, umbilical cord mesenchymal stem/stromal cells; EVs, extracellular vesicles; TNTs, tunneling nanotubes; $C X S$, connexins; LPS, lipopolysaccharide; miRNA, microRNA; LAD, left anterior descending; Wnt, wingless type; $A R D S$, acute respiratory distress syndrome; $G P X$, glutathione peroxidase; $S P$, specificity protein 
modulation function in rat cortical neurons suffering ischemia via mammalian target of rapamycin signaling both in vitro and in vivo [55]. Although MSC death modulation function depending on paracrine factors may occur, this does not exclude implication of other modes of actions with either requirement of cell-to-cell contact, such as with Cx gap junctions and/or TNTs, or without requirement of cell-to-cell contact, such as with EVs (Fig. 1).

\section{$\mathrm{Ca}^{2+}$ ion exchange via $\mathrm{Cx}$ gap junctions}

Intercellular communications via $\mathrm{Cx}$ gap junctions are critically involved in biological processes [78]. Indeed, gap junction channels facilitate the intercellular exchange between cells of ions and small molecules $<1$ $\mathrm{kDa}$, influencing cell functions and cell survival in tissues [78]. Hence, preclinical studies showed that BM-MSCs from rat can prevent RCD in $\mathrm{H} 9 \mathrm{c} 2$ cardiomyoblasts via direct cell-to-cell interactions, after ischemic damage induced in vitro by oxygen and glucose deprivation [41]. Other preclinical studies of rat BM-MSCs demonstrated specifically that Cx43 gap junctions contribute to BM-MSC survival under hypoxic conditions $[67,79]$. Furthermore, upregulation of Cx43 expression by genetic manipulation of those BM-MSCs significantly improved the therapeutic efficacy in a model of myocardial infarction induced by ligation of the left anterior descending (LAD) artery $[67,79]$. Concomitantly, BM-MSCs overexpressing Cx43 can produce significantly more pro-survival molecules, such as Bcl-2, and fewer pro-death molecules, such as Bax, which suggests a role for $\mathrm{Cx} 43$ in the function of MSCs to prevent RCD processes in cardiomyocytes [67, 79]. Besides, adoptive transfer of mouse or human BM-MSCs into the lung protected against acute lung injury (ALI) induced by lipopolysaccharide in mouse [43]. The mode of action of BM-MSCs that led to improved alveolar cell bioenergetics and reducing cell mortality mostly depended on Cx43 gap junctions. Indeed, the mode of action involved at least $\mathrm{Ca}^{2+}$ exchange via $\mathrm{Cx} 43$ gap junctions between BM-MSCs and unfit alveolar epithelial cells [43].

Human MSCs can express Cx40, 43, and 45, but the formation of homomeric $\mathrm{Cx} 43$ gap junction channels between MSCs themselves and among MSCs and third-party cells is usually detected in vitro in electrophysiological records [80]. Of note, several Cx combinations forming heteromeric gap junction channels may occur, yet these appear to be much less predominant than homomeric Cx43 gap junctions [80]. Thus, homomeric Cx43 channels between human MSCs and cardiomyocytes are functional and might play a role in cell survival [80]. Remarkably, human MSCs can form a dynamic syncytium via $\mathrm{Cx} 43$ and $\mathrm{Cx} 45$ gap junctions that regulate CXCL12 secretion while favoring survival and homeostasis of HSCs [60]. In a mouse model of BM mononuclear cell transplantation, the mode of action implied $\mathrm{Ca}^{2+}$ exchange via $\mathrm{Cx} 43$ and $\mathrm{Cx} 45$ gap junctions among MSCs that permits signaling by cAMP-protein

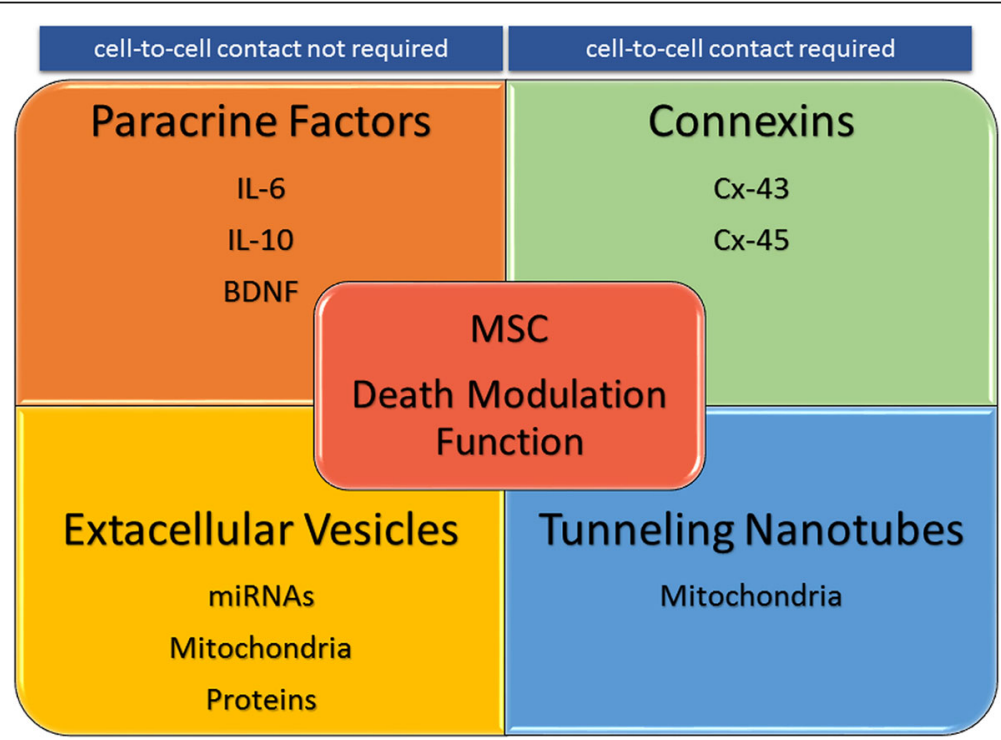

Fig. 1 Diagram of possible modes of actions involved in MSC death modulation function. MSC death modulation function might have a mode of action involving paracrine factors (such as IL-6, IL-10, and BDNF) and/or extracellular vesicles (such as for transporting miRNAs, mitochondria, and proteins) were cell-to-cell contact is not required. By contrast, MSC death modulation function might have a mode of action involving connexins (such as CX-43 and Cx-45) and/or tunneling nanotubes (such as for transporting mitochondria) were cell-to-cell contact is absolutely required. IL, interleukin; BDNF, brain-derived neurotrophic factor; Cx, connexin; miRNAs, microRNAs 
kinase A and CXCL12 secretion by MSCs, ultimately enhancing the cell survival of HSCs, both in vitro and in vivo [60].

Moreover, in human multiple myeloma (MM) cell lines including RPMI 8266, U266, and XG7, Cx43-gap junctions formed between human MSCs and MM cells reduced bortezomib-induced $\mathrm{RCD}$, such as apoptosis and/or necroptosis, with the function reversible by gap junction inhibitors [66]. Of note, MSCs from MM patients express significantly more $\mathrm{Cx} 43$ than do MSCs from healthy individuals, which suggests a role for $\mathrm{Cx} 43$ expressed by MSCs in MM cell survival within BM [66, 68]. Hence, RCD occurring in unfit MM cells might be prevented by MSCs via Cx43 gap junction interactions, thereby allowing their growth, but would have rather noxious consequences in MM pathogenesis $[66,68]$.

\section{Transfer of mitochondria via TNTs}

Accumulating evidence suggests that MSCs rescue unfit somatic cells by transfer of mitochondria through membrane channels called TNTs [17]. TNTs are biological structures with a diameter of up to $0.7 \mu \mathrm{m}$ that are sustained by cytoskeleton structures made of $\mathrm{f}$-actin microfilaments and/or $\alpha / \beta$-tubulin microtubules [81]. TNTs are thought to support rapid transfer of cellular materials including large organelles from a donor cell to a targeted recipient cell [81]. Intercellular transfer of mitochondria from MSCs to somatic cells was first reported by Spees et al. The authors demonstrated that active mitochondria transfer can rescue aerobic respiration in epithelial $\mathrm{A} 549 \rho^{0}$ cells harboring malfunctioning mitochondria induced by ethidium bromide in vitro [27]. Yet, at that time, the results did not clearly establish whether mitochondria were transferred to unfit epithelial cells solely through TNTs or EVs or both [27]. After adoptive transfer into a rat experimental model of pulmonary diseases induced by cigarette smoke, human MSCs were found to reduce cell death and tissue fibrosis [82]. The reduced lung tissue damage in vivo was associated with transfer of mitochondria from human MSCs to rat airway epithelial cells [82]. As well, transfer of mitochondria from human MSCs to human BEAS-2B bronchial epithelial cells exposed to cigarette smoke in vitro also occurs via TNTs, because inhibition of TNT formation impeded mitochondria transfer, thereby contributing to decreased cell viability [82].

Furthermore, in an ALI mouse experimental model induced by lipopolysaccharide, rat and human MSCs protected against ALI pathology by decreasing RCD occurring in alveolar epithelial cells and by improving alveolar epithelial cell bioenergetics in part via mitochondria transfer through TNTs, both in vitro and in vivo [43]. This finding was further sustained when mitochondria rho GTPase 1 (Miro-1) was identified as a critical factor enabling MSCs to transfer mitochondria through TNT microtubules to unfit tracheal and alveolar epithelial cells, thus decreasing RCD including apoptosis [38]. Indeed, Miro-1 appears essential to facilitate mitochondria trafficking from human MSCs to unfit tracheal and alveolar epithelial cells via TNTs. This process decreased apoptosis in lung epithelial cells in vivo, in mouse models of both rotenone-induced airway injury and allergic airway inflammation. In the same study, the authors underlined that MSC secretion of immunosuppressive factors such as nitric oxide, transforming growth factor $\beta$, interleukin 10, and prostaglandin E2 were not significantly involved in the beneficial effects of MSCs in airway injury and inflammation [38]. This last finding suggests and favors a hypothesis considering a less predominant paracrine effect via the MSC immunosuppression function than an MSC death modulation function via TNT mitochondria transfer [38].

Importantly, MSCs donating their own mitochondria via TNTs to unfit somatic cells seem to occur once danger signals from affected cells are sensed and integrated by MSCs, including the sensing of mitochondria released by dying cells [46]. Indeed, human cardiomyoblasts and endothelial cells with RCD induced in vitro by hydrogen peroxide or doxorubicin release their mitochondria that can be engulfed by MSCs, thus initiating MSCs rescuing dying cells [46]. This requirement has been demonstrated in vivo in a mouse model of myocardial infarction induced by LAD artery ligation: inhibition of mitophagy abrogated the MSC death modulation function toward cardiomyocyte apoptosis [46].

\section{Transfer of bioactive miRNAs and proteins via EVs}

EVs are small membrane vesicles of about $40 \mathrm{~nm}$ to $1 \mu \mathrm{m}$ in diameter that are derived from multivesicular bodies and/or from the plasma membrane of cells. EVs are released by MSCs containing biological materials that can be transferred to targeted recipient cells modifying their biology [83]. This mode of action is thought to carry significant parts of the intercellular communication between MSCs, adult stem cells, progenitors, and somatic cells, both locally and systemically [83]. MSCs produce EVs containing bioactive molecules, such as selective miRNAs, and specific bioactive proteins, such as enzymes [72, 83]. The content of EVs produced by MSCs is likely transferred after EVs fuse with the plasma membrane of targeted recipient cells or after EV endocytosis or phagocytosis by those recipient cells $[72,83]$. EVs derived from MSCs have a critical impact on recipient cell biology, particularly improving cell bioenergetics, cell metabolism, and cell survival of unfit adult stem cells and somatic cells [40, 51, 53, 70-73, 84, 85].

The human MSC transfer of miRNAs via EVs ameliorated the silicosis pathophysiology and RCD-mediated 
lung injury in vivo in a mouse model [73]. Moreover, miRNA transfer via EVs produced by human MSCs alleviated in vivo renal tubular epithelial RCD that can be apoptosis and/or necroptosis induced in vivo by glycerol or cisplatin in severe combined immunodeficient mouse (SCID) $[86,87]$. Of note, co-incubation in vitro of EVs derived from human MSCs with human renal tubular epithelial cells injured by cisplatin or by ATP depletion reduced apoptosis by upregulating $\mathrm{Bcl}-\mathrm{xL}, \mathrm{Bcl}-2$, and BIRC8 pro-survival pathways and downregulating genes involved in RCD, such as caspase-1 and caspase-8 [86, 87]. Mostly, EVs derived from human MSCs likely allow transfer of miRNAs, especially miRNA-24, to renal tubular epithelial cells that modulate cell death pathways ultimately favoring cell survival $[86,88]$. Actually, miRNAs transferred by EVs derived from human MSCs to renal tubular epithelial cells were critical in improving conditions in glycerol-induced acute kidney injury in a SCID mouse model; indeed, depletion of miRNAs using a knockdown method (Drosha knockdown) abolished the therapeutic efficacy of EVs [88]. Furthermore, EVs derived from human MSCs containing miRNA-22 and its transfer to unfit mouse neonatal cardiomyocytes abrogated RCD by apoptosis induced by ischemic stress via direct interactions with methyl $\mathrm{CpG}$ binding protein 2 [89]. As well, EVs derived from human MSCs and containing miRNA-22 significantly reduced fibrosis in a myocardial infarction mouse model induced by LAD artery ligation [89].

Likewise, human MSC-derived EVs contain miRNA let-7 precursors that can mature to let-7a, let-7e, and let-7-5p miRNAs. These let-7a, let-7e, and let-7-5p miRNAs upregulated $\mathrm{Bcl}-2$ and downregulated caspase- 3 and prevented RCD such as apoptosis and autophagy-related cell death in MSCs themselves and in the mouse neuron cell line Neuro2a in vitro when subjected to RCD cell signaling after deprivation of oxygen and glucose [71]. In addition, inhibition of miRNA-21 and miRNA-34a produced by human MSCs deprived of serum increased the apoptosis of MSCs, which suggests an essential role of miRNA-21 and miRNA-34a in preventing RCD in MSCs [72]. Besides, EVs derived from MSCs containing miRNA-21 and miRNA-34a inhibited apoptosis in MCF-7 breast cancer cells and KHOS osteosarcoma cells subjected to RCD signaling both in vitro and in vivo [72]. Similarly, EVs containing miRNA-410 derived from MSCs promoted the growth of lung adenocarcinoma cancer cells in vivo that was associated with downregulation of phosphatase and tensin homolog protein expression, with a decrease in RCD such as cell apoptosis [70].

Of note, the authors of a preclinical study demonstrated that EVs derived from MSCs transported neprilysin, an amyloid $\beta(\mathrm{A} \beta)$-degrading enzyme, capable of reducing both secreted and intracellular $A \beta$ molecules in mouse Neuro2a cells in vitro [90]. Hence, EV delivery of neprilysin to affected neurons with accumulation of $A \beta$ peptides could potentially protect against $A \beta$-induced caspase-1-dependent neuron pyroptosis involved in Alzheimer's disease [90]. Moreover, EVs derived from human MSCs alleviated liver fibrosis and hepatocyte RCD in vivo in a mouse model of acute liver injury induced by carbon tetrachloride $\left(\mathrm{CCl}_{4}\right)$ peritoneal injection [91]. Especially, EVs derived from human MSCs carrying glutathione peroxidase 1 (GPX1) prevented hepatocyte apoptosis and/or necroptosis in a mouse with liver injury induced by $\mathrm{CCl}_{4}$ [92]. GPX1 knockdown revoked the anti-RCD abilities of EVs derived from human MSCs both in vitro and in vivo [92]. Furthermore, EVs derived from human MSCs ameliorated cutaneous healing of skin burn in a rat model [93]. This observation was associated with inhibited RCD by apoptosis in rat epithelial cells via transfer of biologically active Wnt4 to injured cells both in vitro and in vivo [93]. As well, human keratinocytes, HaCATs, after in vitro heat stress-induced RCD, were rescued from apoptosis by EVs derived from human MSCs via transfer of Wnt4 into unfit HaCATs [93]. Similarly, with human-induced pluripotent-derived mesenchymal stem/stromal cells (iPSC-MSCs), it has been shown that EVs produced by iPSC-MSCs contained specificity protein 1 (SP1) transcription factor. iPSC-MSC EV transfer of SP1 to human HK-2 epithelial cells undergoing necroptosis induced by deprivation of oxygen rescues the HK-2 through transcriptional activating of sphingosine kinase 1 [53]. As well, transfer of SP1 via EVs appears critical to inhibit necroptosis occurring in rat renal epithelial cells in vivo in a rat model of acute kidney injury induced by renal pedicle clamping [53].

In addition to MSCs transferring miRNAs and/or proteins via EVs to unfit somatic cells, MSCs may also transfer larger organelles such as mitochondria via EVs to modulate RCD in unfit cells. Indeed, this pathway has been suggested to play a critical role in the transfer of mitochondria to injured alveolar epithelial cells $[43,63]$. The transfer would allow for amelioration of the pathogenesis of acute respiratory distress syndrome in vivo in both preclinical and clinical settings $[63,94]$. The MSC death modulation function may be exploited in the clinic for degenerative and/or inflammatory diseases. For example, in a clinical assay, bronchoalveolar lavage fluid of two patients with acute respiratory distress syndrome who received adoptive transfer of MSCs showed a rapid decrease in levels of cell death biomarkers, including biomarkers of apoptosis and necrosis of alveolar epithelial cells [63]. Fluids were assessed within just a few hours after adoptive transfer of MSCs in both patients and notably several hours before a decrease in inflammatory biomarkers were detected [63]. This finding 
might indicate that the MSC death modulation function is implemented early and therefore is crucial in the beneficial effect observed in this clinical assay $[17,63]$.

\section{Are gap junctions, TNTs, and EVs synergistic to convey MSC death modulation function?}

The MSC death modulation function appears to contribute a part of the therapeutic effects of MSCs for various diseases [17]. This function is implemented predominantly by MSCs through modes of actions implying direct cell-to-cell interactions requiring either cell contact with gap junctions and TNTs, or no cell contact with EVs (Fig. 1). Together, these modes of actions might be interdependent in ultimately controlling the transfer of mitochondria from MSCs to unfit cells for the full potency of the MSC death modulation function. Indeed, recent studies suggested that $\mathrm{Cx} 43$ gap junctions contribute to facilitate TNT- and EV-dependent exchange of biological materials between cells [78]. Thus, the formation of Cx43 gap junctions between MSCs and unfit cells may serve as a beacon by first sensing cell needs via $\mathrm{Ca}^{2+}$ and by directing the transfer of larger biological materials such as proteins and organelles through TNTs and EVs in a circumscribed microenvironment between cells. Therefore, the three individual modes of actions described above likely function synergistically in conveying the MSC death modulation function (Fig. 2).

\section{Conclusion}

MSCs could be a remarkable adult stem cell source for cell therapy and advantageous for responding to various medical demands. Yet, there are obstacles to the development of MSC therapy [8, 9, 15, 17, 26, 76, 95-97]. In some clinical trials of MSC therapy, the clinical benefits were mitigated $[15,76,95,96]$, but in others, the outcome of MSC therapy was more encouraging [63, 98104]. Thus, MSC therapy must be consolidated by refining its efficacy and consistency in therapy of human disorders. A better understanding of MSC biological functions could help assess the potency of MSCs in

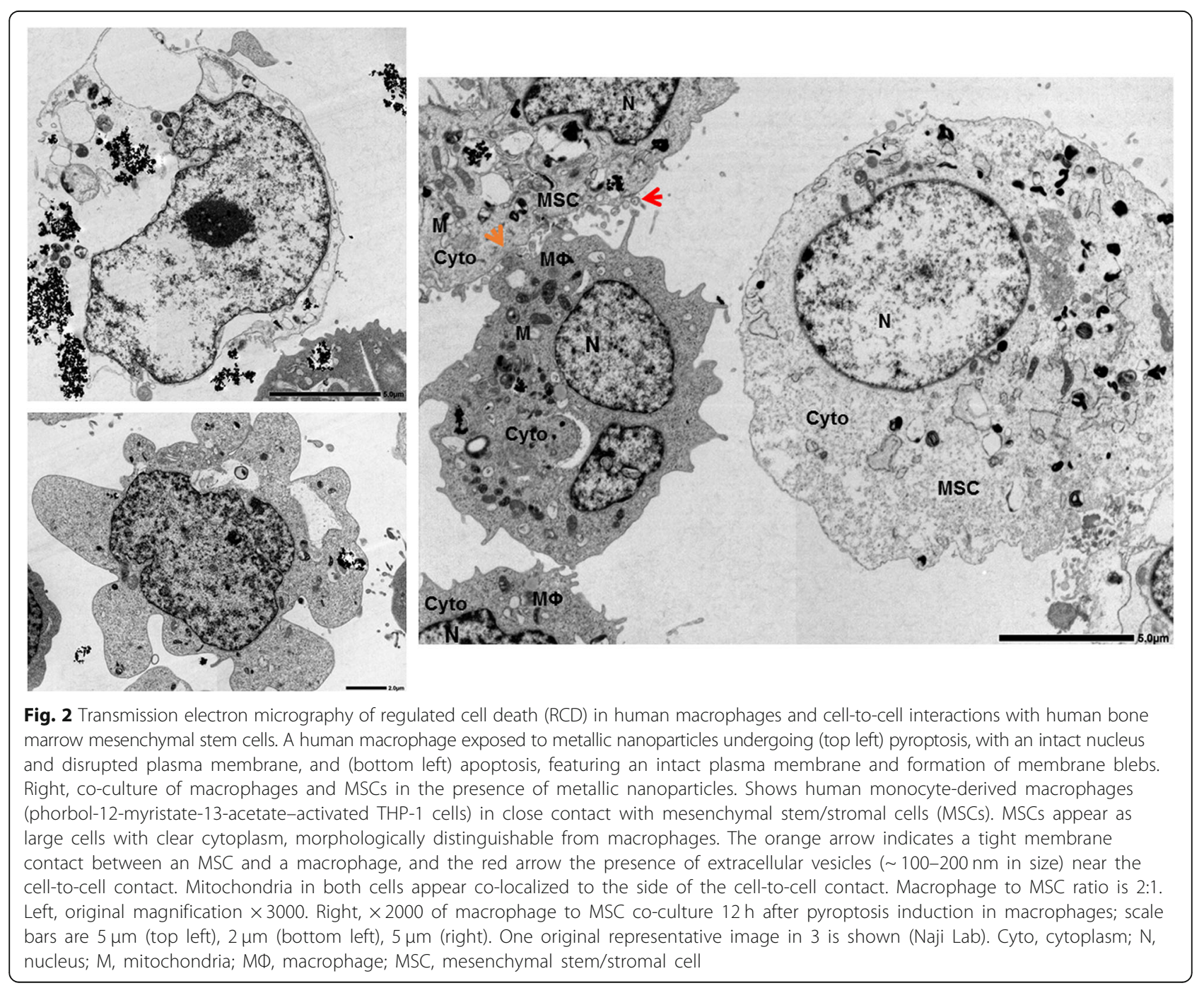


therapeutics and could unlock the knowledge of MSC identity. This understanding includes the MSC death modulation function in particular, which is just being revealed, and whose potential relevance in degenerative and/or inflammatory diseases could be critical. The expression of $\mathrm{Cx}-43$ as well as the mitochondria bioenergetic $(\Delta \psi \mathrm{m})$ and/or mitochondria phenotype (Miro-1) might be good indicators of functional potency for the MSC death modulation function of ex vivo-cultured MSCs and useful biomarkers for identifying MSCs for clinical use.

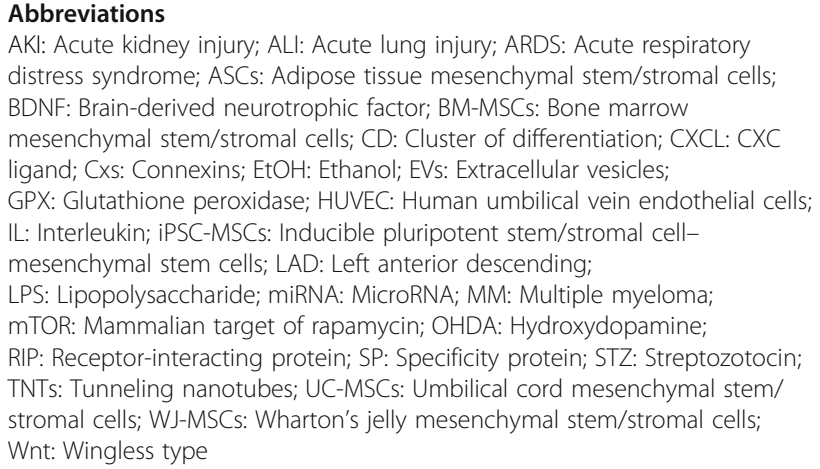

AKI: Acute kidney injury; ALl: Acute lung injury; ARDS: Acute respiratory distress syndrome; ASCs: Adipose tissue mesenchymal stem/stromal cells; BDNF: Brain-derived neurotrophic factor; BM-MSCs: Bone marrow mesenchymal stem/stromal cells; CD: Cluster of differentiation; CXCL: CXC ligand; Cxs: Connexins; EtOH: Ethanol; EVs: Extracellular vesicles; GPX: Glutathione peroxidase; HUVEC: Human umbilical vein endothelial cells; IL: Interleukin; iPSC-MSCs: Inducible pluripotent stem/stromal cellmesenchymal stem cells; LAD: Left anterior descending; LPS: Lipopolysaccharide; miRNA: MicroRNA; MM: Multiple myeloma; mTOR: Mammalian target of rapamycin; OHDA: Hydroxydopamine; RIP: Receptor-interacting protein; SP: Specificity protein; STZ: Streptozotocin TNTs: Tunneling nanotubes; UC-MSCs: Umbilical cord mesenchymal stem/ stromal cells; WJ-MSCs: Wharton's jelly mesenchymal stem/stromal cells; Wnt: Wingless type

\section{Acknowledgements}

The authors thank Dr. Ken-ichi Yagyu of the Science Research Center at Kochi Medical School (KMS), Kochi University, for technical support in transmission electron microscopy.

\section{Funding}

Support for research was provided by Suzuken-Memorial Foundation (Japan) and the Japanese Society for the Promotion of Science (JSPS), Young B KAKENHI (grant no. $17 \mathrm{~K} 15729$ ) to AN. Additional support was provided by intramural funding to AN from KMS, Kochi University, Japan. BF was supported by the program "Exploration Japon, 2018" provided by Campus France (France).

\section{Availability of data and materials}

All data are included in this published article.

\section{Authors' contributions}

AN and NS contributed to establishing the concept conveyed in the manuscript. AN wrote the manuscript and designed the figures and tables. BF, FD, ME, NRF, and NS contributed to the writing and editing of the manuscript. All authors reviewed the manuscript. All authors read and approved the final manuscript.

Ethics approval and consent to participate

Not applicable.

\section{Consent for publication}

Not applicable.

\section{Competing interests}

The authors declare that they have no competing interests.

\section{Publisher's Note}

Springer Nature remains neutral with regard to jurisdictional claims in published maps and institutional affiliations.

\section{Author details}

'Department of Environmental Medicine, Cooperative Medicine Unit, Research and Education Faculty, Medicine Science Cluster, Kochi Medical
School (KMS), Kochi University, Kohasu, Oko-Cho, Nankoku City, Kochi Prefecture 783-8505, Japan. ${ }^{2}$ CEA-Université Paris Sud INSERM U1184, IDMIT Department, IBFJ, DRF, Fontenay-aux-Roses, France. ${ }^{3}$ STROMALab, UMR 5273 CNRS, INSERM U1031, Etablissement Français du Sang (EFS) Occitanie, Université de Toulouse, Toulouse, France. ${ }^{4}$ CEA, DRF-Institut Francois Jacob, Division de recherche en hématologie et immunologie (SRHI), Hôpital Saint-Louis, Paris, France.

Published online: 13 February 2019

\section{References}

1. Sacchetti B, et al. No identical "mesenchymal stem cells" at different times and sites: human committed progenitors of distinct origin and differentiation potential are incorporated as adventitial cells in microvessels. Stem Cell Reports. 2016;6:897-913. https://doi.org/10.1016/ j.stemcr.2016.05.011

2. Wagner $W$, et al. The heterogeneity of human mesenchymal stem cell preparations--evidence from simultaneous analysis of proteomes and transcriptomes. Exp Hematol. 2006;34:536-48. https://doi.org/10.1016/j. exphem.2006.01.002.

3. Pevsner-Fischer M, Levin S, Zipori D. The origins of mesenchymal stromal cell heterogeneity. Stem Cell Rev. 2011;7:560-8. https://doi.org/10.1007/ s12015-011-9229-7.

4. Han ZC, Du WJ, Han ZB, Liang L. New insights into the heterogeneity and functional diversity of human mesenchymal stem cells. Biomed Mater Eng. 2017;28:S29-45. https://doi.org/10.3233/BME-171622.

5. Phinney DG. Functional heterogeneity of mesenchymal stem cells: implications for cell therapy. J Cell Biochem. 2012;113:2806-12. https://doi. org/10.1002/jcb.24166

6. LV FJ, Tuan RS, Cheung KM, Leung VY. Concise review: the surface markers and identity of human mesenchymal stem cells. Stem Cells. 2014;32:140819. https://doi.org/10.1002/stem.1681

7. Dominici $\mathrm{M}$, et al. Minimal criteria for defining multipotent mesenchymal stromal cells. The International Society for Cellular Therapy position statement. Cytotherapy. 2006;8:315-7. https://doi.org/10.1080/ 14653240600855905

8. Galipeau J, Krampera M. The challenge of defining mesenchymal stromal cell potency assays and their potential use as release criteria. Cytotherapy. 2015;17:125-7. https://doi.org/10.1016/.j.cyt.2014.12.008.

9. Galipeau J, et al. International Society for Cellular Therapy perspective on immune functional assays for mesenchymal stromal cells as potency release criterion for advanced phase clinical trials. Cytotherapy. 2016;18:151-9. https://doi.org/10.1016/j.jcyt.2015.11.008.

10. Le Blanc K, Davies LC. MSCs-cells with many sides. Cytotherapy. 2018;20: 273-8. https://doi.org/10.1016/j.jcyt.2018.01.009.

11. Mindaye ST, Lo Surdo J, Bauer SR, Alterman MA. The proteomic dataset for bone marrow derived human mesenchymal stromal cells: effect of in vitro passaging. Data Brief. 2015;5:864-70. https://doi.org/10.1016/j. dib.2015.10.020

12. Mindaye ST, Ra M, Lo Surdo J, Bauer SR, Alterman MA. Improved proteomic profiling of the cell surface of culture-expanded human bone marrow multipotent stromal cells. J Proteome. 2013;78:1-14. https://doi.org/10.1016/ j.jprot.2012.10.028

13. Mindaye ST, Ra M, Lo Surdo JL, Bauer SR, Alterman MA. Global proteomic signature of undifferentiated human bone marrow stromal cells: evidence for donor-to-donor proteome heterogeneity. Stem Cell Res. 2013;11:793805. https://doi.org/10.1016/j.scr.2013.05.006.

14. Mindaye ST, Surdo JL, Bauer SR, Alterman MA. System-wide survey of proteomic responses of human bone marrow stromal cells (hBMSCs) to in vitro cultivation. Stem Cell Res. 2015;15:655-64. https://doi.org/10.1016/.scr. 2015.09.013.

15. Phinney DG, et al. MSCs: science and trials. Nat Med. 2013;19:812. https:// doi.org/10.1038/nm.3220.

16. da Silva Meirelles L, Caplan Al, Nardi NB. In search of the in vivo identity of mesenchymal stem cells. Stem Cells. 2008;26:2287-99. https://doi.org/10. 1634/stemcells.2007-1122.

17. Naji $A$, et al. Rationale for determining the functional potency of mesenchymal stem cells in preventing regulated cell death for therapeutic use. Stem Cells Transl Med. 2017;6:713-9. https://doi.org/10. 5966/sctm.2016-0289. 
18. Samsonraj RM, et al. Establishing criteria for human mesenchymal stem cell potency. Stem Cells. 2015;33:1878-91. https://doi.org/10.1002/stem.1982.

19. Singh P, Fukuda S, Liu L, Chitteti BR, Pelus LM. Survivin is required for mouse and human bone marrow mesenchymal stromal cell function. Stem Cells. 2018;36:123-9. https://doi.org/10.1002/stem.2727.

20. Turinetto V, Vitale E, Giachino C. Senescence in human mesenchymal stem cells: functional changes and implications in stem cell-based therapy. Int J Mol Sci. 2016;17. https://doi.org/10.3390/ijms17071164.

21. Caplan Al. Mesenchymal stem cells. J Orthop Res. 1991;9:641-50. https://doi. org/10.1002/jor.1100090504.

22. Caplan Al. Adult mesenchymal stem cells for tissue engineering versus regenerative medicine. J Cell Physiol. 2007;213:341-7. https://doi.org/10. 1002/jcp.21200.

23. Caplan Al. Why are MSCs therapeutic? New data: new insight. J Pathol. 2009;217:318-24. https://doi.org/10.1002/path.2469.

24. Caplan Al, Dennis JE. Mesenchymal stem cells as trophic mediators. J Cell Biochem. 2006:98:1076-84. https://doi.org/10.1002/jcb.20886.

25. Ma S, et al. Immunobiology of mesenchymal stem cells. Cell Death Differ. 2014;21:216-25. https://doi.org/10.1038/cdd.2013.158.

26. Naji $A$, et al. Concise review: combining human leukocyte antigen $G$ and mesenchymal stem cells for immunosuppressant biotherapy. Stem Cells. 2013;31:2296-303. https://doi.org/10.1002/stem.1494.

27. Spees $\mathrm{J}$, Lee RH, Gregory CA. Mechanisms of mesenchymal stem/stromal cell function. Stem Cell Res Ther. 2016;7:125. https://doi.org/10.1186/s13287016-0363-7.

28. Bianco P, Robey PG, Simmons PJ. Mesenchymal stem cells: revisiting history, concepts, and assays. Cell Stem Cell. 2008;2:313-9. https://doi.org/10.1016/j. stem.2008.03.002

29. Li F, Guo X, Chen SY. Function and therapeutic potential of mesenchymal stem cells in atherosclerosis. Front Cardiovasc Med. 2017:4:32. https://doi. org/10.3389/fcrm.2017.00032

30. Nombela-Arrieta C, Ritz J, Silberstein LE. The elusive nature and function of mesenchymal stem cells. Nat Rev Mol Cell Biol. 2011;12:126-31. https://doi. org/10.1038/nrm3049.

31. Charbord P. Bone marrow mesenchymal stem cells: historical overview and concepts. Hum Gene Ther. 2010;21:1045-56. https://doi.org/10.1089/hum. 2010.115 .

32. Chamberlain G, Fox J, Ashton B, Middleton J. Concise review: mesenchymal stem cells: their phenotype, differentiation capacity, immunological features, and potential for homing. Stem Cells. 2007;25:2739-49. https://doi.org/10. 1634/stemcells.2007-0197.

33. Linkermann A, Stockwell BR, Krautwald S, Anders HJ. Regulated cell death and inflammation: an auto-amplification loop causes organ failure. Nat Rev Immunol. 2014;14:759-67. https://doi.org/10.1038/nri3743.

34. Hotchkiss RS, Strasser A, McDunn JE, Swanson PE. Cell death. N Engl J Med. 2009;361:1570-83. https://doi.org/10.1056/NEJMra0901217.

35. Galluzzi L, Bravo-San Pedro JM, Kepp O, Kroemer G. Regulated cell death and adaptive stress responses. Cell Mol Life Sci. 2016;73:2405-10. https://doi. org/10.1007/s00018-016-2209-y.

36. Galluzzi L, et al. Molecular mechanisms of cell death: recommendations of the nomenclature committee on cell death 2018. Cell Death Differ. 2018;25: 486-541. https://doi.org/10.1038/s41418-017-0012-4.

37. Safa AR. Resistance to cell death and its modulation in cancer stem cells Crit Rev Oncog. 2016;21:203-19. https://doi.org/10.1615/CritRevOncog. 2016016976.

38. Ahmad T, et al. Miro1 regulates intercellular mitochondrial transport \& enhances mesenchymal stem cell rescue efficacy. EMBO J. 2014;33:9941010. https://doi.org/10.1002/embj.201386030.

39. Benvenuto $F$, et al. Human mesenchymal stem cells promote survival of $T$ cells in a quiescent state. Stem Cells. 2007;25:1753-60. https://doi.org/10. 1634/stemcells.2007-0068.

40. Crompot $\mathrm{E}$, et al. Extracellular vesicles of bone marrow stromal cells rescue chronic lymphocytic leukemia B cells from apoptosis, enhance their migration and induce gene expression modifications. Haematologica. 2017: 102:1594-604. https://doi.org/10.3324/haematol.2016.163337.

41. Cselenyak A, Pankotai E, Horvath EM, Kiss L, Lacza Z. Mesenchymal stem cells rescue cardiomyoblasts from cell death in an in vitro ischemia model via direct cell-to-cell connections. BMC Cell Biol. 2010;11:29. https://doi.org/ 10.1186/1471-2121-11-29

42. Drouet $M$, et al. Mesenchymal stem cells rescue CD34+ cells from radiationinduced apoptosis and sustain hematopoietic reconstitution after coculture and cografting in lethally irradiated baboons: is autologous stem cell therapy in nuclear accident settings hype or reality? Bone Marrow Transplant. 2005;35:1201-9. https://doi.org/10.1038/sj.bmt.1704970.

43. Islam MN, et al. Mitochondrial transfer from bone-marrow-derived stromal cells to pulmonary alveoli protects against acute lung injury. Nat Med. 2012; 18:759-65. https://doi.org/10.1038/nm.2736.

44. Liu K, et al. Mesenchymal stem cells rescue injured endothelial cells in an in vitro ischemia-reperfusion model via tunneling nanotube like structuremediated mitochondrial transfer. Microvasc Res. 2014;92:10-8. https://doi. org/10.1016/j.mvr.2014.01.008.

45. Liu L, et al. Mesenchymal stem cells inhibition of chronic ethanol-induced oxidative damage via upregulation of phosphatidylinositol-3-kinase/Akt and modulation of extracellular signal-regulated kinase $1 / 2$ activation in PC12 cells and neurons. Neuroscience. 2010;167:1115-24. https://doi.org/10.1016/ j.neuroscience.2010.01.057.

46. Mahrouf-Yorgov M, et al. Mesenchymal stem cells sense mitochondria released from damaged cells as danger signals to activate their rescue properties. Cell Death Differ. 2017;24:1224-38. https://doi.org/10.1038/cdd. 2017.51.

47. Maqbool M, Vidyadaran S, George E, Ramasamy R. Human mesenchymal stem cells protect neutrophils from serum-deprived cell death. Cell Biol Int. 2011;35:1247-51. https://doi.org/10.1042/CBI20110070.

48. Naji $A$, et al. Endocytosis of indium-tin-oxide nanoparticles by macrophages provokes pyroptosis requiring NLRP3-ASC-Caspase 1 axis that can be prevented by mesenchymal stem cells. Sci Rep. 2016;6:26162. https://doi. org/10.1038/srep26162.

49. Nwabo Kamdje AH, et al. Notch-3 and Notch-4 signaling rescue from apoptosis human B-ALL cells in contact with human bone marrow-derived mesenchymal stromal cells. Blood. 2011;118:380-9. https://doi.org/10.1182/ blood-2010-12-326694.

50. Scheibe F, Klein O, Klose J, Priller J. Mesenchymal stromal cells rescue cortical neurons from apoptotic cell death in an in vitro model of cerebral ischemia. Cell Mol Neurobiol. 2012;32:567-76. https://doi.org/10.1007/ s10571-012-9798-2.

51. Wen $\mathrm{S}$, et al. Mesenchymal stromal cell-derived extracellular vesicles rescue radiation damage to murine marrow hematopoietic cells. Leukemia. 2016; 30:2221-31. https://doi.org/10.1038/leu.2016.107.

52. Yang WJ, Li SH, Weisel RD, Liu SM, Li RK. Cell fusion contributes to the rescue of apoptotic cardiomyocytes by bone marrow cells. J Cell Mol Med. 2012;16:3085-95. https://doi.org/10.1111/j.1582-4934.2012.01600.x.

53. Yuan $X$, et al. Extracellular vesicles from human-induced pluripotent stem cell-derived mesenchymal stromal cells (hiPSC-MSCs) protect against renal ischemia/reperfusion injury via delivering specificity protein (SP1) and transcriptional activating of sphingosine kinase 1 and inhibiting necroptosis. Cell Death Dis. 2017:8:3200. https://doi.org/10.1038/s41419-017-0041-4.

54. Zhao K, et al. Bone marrow-derived mesenchymal stem cells ameliorate chronic high glucose-induced beta-cell injury through modulation of autophagy. Cell Death Dis. 2015;6:e1885. https://doi.org/10.1038/cddis.2015.230

55. Zheng Z, et al. Mesenchymal stem cells protect against hypoxia-ischemia brain damage by enhancing autophagy through brain derived neurotrophic factor/mammalin target of rapamycin signaling pathway. Stem Cells. 2018. https://doi.org/10.1002/stem.2808.

56. Zilka N, et al. Mesenchymal stem cells rescue the Alzheimer's disease cell model from cell death induced by misfolded truncated tau. Neuroscience. 2011;193:330-7. https://doi.org/10.1016/j.neuroscience.2011.06.088.

57. Kong D, et al. Mesenchymal stem cells protect neurons against hypoxicischemic injury via inhibiting parthanatos, necroptosis, and apoptosis, but not autophagy. Cell Mol Neurobiol. 2017;37:303-13. https://doi.org/10.1007/ s10571-016-0370-3.

58. Raffaghello L, et al. Human mesenchymal stem cells inhibit neutrophil apoptosis: a model for neutrophil preservation in the bone marrow niche. Stem Cells. 2008:26:151-62. https://doi.org/10.1634/stemcells.2007-0416.

59. Greenbaum A, et al. CXCL12 in early mesenchymal progenitors is required for haematopoietic stem-cell maintenance. Nature. 2013:495:227-30. https:// doi.org/10.1038/nature11926

60. Schajnovitz A, et al. CXCL12 secretion by bone marrow stromal cells is dependent on cell contact and mediated by connexin-43 and connexin-45 gap junctions. Nat Immunol. 2011;12:391-8. https://doi.org/10.1038/ni.2017.

61. Wang J, et al. Interleukin-10 secreted by mesenchymal stem cells attenuates acute liver failure through inhibiting pyroptosis. Hepatol Res. 2018;48:E194202. https://doi.org/10.1111/hepr.12969. 
62. Xiao C, et al. Transplanted mesenchymal stem cells reduce autophagic flux in infarcted hearts via the exosomal transfer of mir-125b. Circ Res. 2018. https://doi.org/10.1161/CIRCRESAHA.118.312758.

63. Simonson $\mathrm{OE}$, et al. In vivo effects of mesenchymal stromal cells in two patients with severe acute respiratory distress syndrome. Stem Cells Transl Med. 2016;5:845. https://doi.org/10.5966/sctm.2015-0021erratum.

64. Kim SY, et al. Mesenchymal stem cell-conditioned media recovers lung fibroblasts from cigarette smoke-induced damage. Am J Physiol Lung Cell Mol Physiol. 2012;302:L891-908. https://doi.org/10.1152/ajplung.00288.2011.

65. Li N, Sarojini H, An J, Wang E. Prosaposin in the secretome of marrow stromaderived neural progenitor cells protects neural cells from apoptotic death. J Neurochem. 2010;112:1527-38. https://doi.org/10.1111/j.1471-4159.2009.06565.x

66. Fu J. Cx43 expressed on bone marrow stromal cells plays an essential role in multiple myeloma cell survival and drug resistance. Arch Med Sci. 2017; 13:236-45. https://doi.org/10.5114/aoms.2017.64722.

67. Wang $D$, et al. Connexin43 promotes survival of mesenchymal stem cells in ischaemic heart. Cell Biol Int. 2010;34:415-23. https://doi.org/10.1042/ CBI20090118.

68. Zhang $X$, et al. Up-regulation of connexin-43 expression in bone marrow mesenchymal stem cells plays a crucial role in adhesion and migration of multiple myeloma cells. Leuk Lymphoma. 2015;56:211-8. https://doi.org/10. 3109/10428194.2014.913289.

69. Han $\mathrm{H}$, et al. Bone marrow-derived mesenchymal stem cells rescue injured $\mathrm{H} 9 \mathrm{c} 2$ cells via transferring intact mitochondria through tunneling nanotubes in an in vitro simulated ischemia/reperfusion model. Mol Med Rep. 2016;13: 1517-24. https://doi.org/10.3892/mmr.2015.4726.

70. Dong $L$, et al. Human umbilical cord mesenchymal stem cell-derived extracellular vesicles promote lung adenocarcinoma growth by transferring miR-410. Cell Death Dis. 2018;9:218. https://doi.org/10.1038/s41419-018-0323-5.

71. Joerger-Messerli MS, et al. Extracellular vesicles derived from Wharton's jelly mesenchymal stem cells prevent and resolve programmed cell death mediated by perinatal hypoxia-ischemia in neuronal cells. Cell Transplant. 2018;27:168-80. https://doi.org/10.1177/0963689717738256.

72. Vallabhaneni $\mathrm{KC}$, et al. Extracellular vesicles from bone marrow mesenchymal stem/stromal cells transport tumor regulatory microRNA, proteins, and metabolites. Oncotarget. 2015;6:4953-67. https://doi.org/10. 18632/oncotarget.3211.

73. Phinney DG, et al. Mesenchymal stem cells use extracellular vesicles to outsource mitophagy and shuttle microRNAs. Nat Commun. 2015;6:8472. https://doi.org/10.1038/ncomms9472.

74. Gao F, et al. Mesenchymal stem cells and immunomodulation: current status and future prospects. Cell Death Dis. 2016;7:e2062. https://doi.org/10. 1038/cddis.2015.327

75. Hodgkinson CP, Bareja A, Gomez JA, Dzau VJ. Emerging concepts in paracrine mechanisms in regenerative cardiovascular medicine and biology. Circ Res. 2016;118:95-107. https://doi.org/10.1161/CIRCRESAHA.115.305373.

76. Trounson A, McDonald C. Stem cell therapies in clinical trials: progress and challenges. Cell Stem Cell. 2015;17:11-22. https://doi.org/10.1016/j.stem. 2015.06.007

77. Hofer HR, Tuan RS. Secreted trophic factors of mesenchymal stem cells support neurovascular and musculoskeletal therapies. Stem Cell Res Ther. 2016;7:131. https://doi.org/10.1186/s13287-016-0394-0.

78. Ribeiro-Rodrigues TM, Martins-Marques T, Morel S, Kwak BR, Girao H. Role of connexin 43 in different forms of intercellular communication - gap junctions, extracellular vesicles and tunnelling nanotubes. J Cell Sci. 2017; 130:3619-30. https://doi.org/10.1242/jcs.200667.

79. Wang $D$, et al. Mesenchymal stem cell injection ameliorates the inducibility of ventricular arrhythmias after myocardial infarction in rats. Int J Cardiol. 2011;152:314-20. https://doi.org/10.1016/j.jijcard.2010.07.025.

80. Valiunas $V$, et al. Human mesenchymal stem cells make cardiac connexins and form functional gap junctions. J Physiol. 2004;555:617-26. https://doi. org/10.1113/jphysiol.2003.058719.

81. Gerdes HH, Carvalho RN. Intercellular transfer mediated by tunneling nanotubes. Curr Opin Cell Biol. 2008;20:470-5. https://doi.org/10.1016/j.ceb.2008.03.005.

82. Li $X$, et al. Mitochondrial transfer of induced pluripotent stem cell-derived mesenchymal stem cells to airway epithelial cells attenuates cigarette smoke-induced damage. Am J Respir Cell Mol Biol. 2014;51:455-65. https:// doi.org/10.1165/rcmb.2013-05290C

83. EL Andaloussi S, Mager I, Breakefield XO, Wood MJ. Extracellular vesicles: biology and emerging therapeutic opportunities. Nat Rev Drug Discov. 2013;12:347-57. https://doi.org/10.1038/nrd3978.
84. Harting MT, et al. Inflammation-stimulated mesenchymal stromal cellderived extracellular vesicles attenuate inflammation. Stem Cells. 2018;36: 79-90. https://doi.org/10.1002/stem.2730.

85. Spinosa M, et al. Human mesenchymal stromal cell-derived extracellular vesicles attenuate aortic aneurysm formation and macrophage activation via microRNA147. FASEB J. 2018,fj201701138RR. https://doi.org/10.1096/fj.201701138RR.

86. Bruno $S$, et al. Microvesicles derived from mesenchymal stem cells enhance survival in a lethal model of acute kidney injury. PLoS One. 2012;7:e33115. https://doi.org/10.1371/journal.pone.0033115.

87. Bruno S, et al. Mesenchymal stem cell-derived microvesicles protect against acute tubular injury. J Am Soc Nephrol. 2009;20:1053-67. https://doi.org/10. 1681/ASN.2008070798.

88. Collino $\mathrm{F}$, et al. AKI recovery induced by mesenchymal stromal cell-derived extracellular vesicles carrying microRNAs. J Am Soc Nephrol. 2015;26:234960. https://doi.org/10.1681/ASN.2014070710.

89. Feng Y, Huang W, Wani M, Yu X, Ashraf M. Ischemic preconditioning potentiates the protective effect of stem cells through secretion of exosomes by targeting Mecp2 via miR-22. PLoS One. 2014;9:e88685. https:// doi.org/10.1371/journal.pone.0088685.

90. Katsuda T, et al. Human adipose tissue-derived mesenchymal stem cells secrete functional neprilysin-bound exosomes. Sci Rep. 2013;3:1197. https:// doi.org/10.1038/srep01197.

91. Li T, et al. Exosomes derived from human umbilical cord mesenchymal stem cells alleviate liver fibrosis. Stem Cells Dev. 2013;22:845-54. https://doi. org/10.1089/scd.2012.0395.

92. Yan $Y$, et al. hucMSC exosome-derived GPX1 is required for the recovery of hepatic oxidant injury. Mol Ther. 2017;25:465-79. https://doi.org/10.1016/j. ymthe.2016.11.019.

93. Zhang B, et al. HucMSC-exosome mediated-Wnt4 signaling is required for cutaneous wound healing. Stem Cells. 2015;33:2158-68. https://doi.org/10. 1002/stem.1771.

94. Morrison TJ, et al. Mesenchymal stromal cells modulate macrophages in clinically relevant lung injury models by extracellular vesicle mitochondrial transfer. Am J Respir Crit Care Med. 2017;196:1275-86. https://doi.org/10. 1164/rccm.201701-01700C.

95. Galipeau J. The mesenchymal stromal cells dilemma--does a negative phase III trial of random donor mesenchymal stromal cells in steroid-resistant graft-versus-host disease represent a death knell or a bump in the road? Cytotherapy. 2013;15:2-8. https://doi.org/10.1016/j.jcyt.2012.10.002.

96. Galipeau J, Sensebe L. Mesenchymal stromal cells: clinical challenges and therapeutic opportunities. Cell Stem Cell. 2018;22:824-33. https://doi.org/10. 1016/j.stem.2018.05.004.

97. Squillaro T, Peluso G, Galderisi U. Clinical trials with mesenchymal stem cells: an update. Cell Transplant. 2016;25:829-48. https://doi.org/10.3727/ $096368915 \times 689622$.

98. Alvaro-Gracia JM, et al. Intravenous administration of expanded allogeneic adipose-derived mesenchymal stem cells in refractory rheumatoid arthritis (Cx611): results of a multicentre, dose escalation, randomised, single-blind, placebo-controlled phase Ib/lla clinical trial. Ann Rheum Dis. 2017;76:196202. https://doi.org/10.1136/annrheumdis-2015-208918.

99. Aoyama T, et al. An exploratory clinical trial for idiopathic osteonecrosis of femoral head by cultured autologous multipotent mesenchymal stromal cells augmented with vascularized bone grafts. Tissue Eng Part B Rev. 2014; 20:233-42. https://doi.org/10.1089/ten.TEB.2014.0090.

100. Detry O, et al. Infusion of mesenchymal stromal cells after deceased liver transplantation: a phase I-II, open-label, clinical study. J Hepatol. 2017;67:4755. https://doi.org/10.1016/j.jhep.2017.03.001.

101. Petrou P, et al. Safety and clinical effects of mesenchymal stem cells secreting neurotrophic factor transplantation in patients with amyotrophic lateral sclerosis: results of phase $1 / 2$ and 2a clinical trials. JAMA Neurol. 2016; 73:337-44. https://doi.org/10.1001/jamaneurol.2015.4321.

102. Connick P, et al. Autologous mesenchymal stem cells for the treatment of secondary progressive multiple sclerosis: an open-label phase 2a proof-ofconcept study. Lancet Neurol. 2012;11:150-6. https://doi.org/10.1016/S14744422(11)70305-2.

103. Le Blanc K, et al. Mesenchymal stem cells for treatment of steroid-resistant, severe, acute graft-versus-host disease: a phase II study. Lancet. 2008;371: 1579-86. https://doi.org/10.1016/S0140-6736(08)60690-X.

104. Le Blanc K, et al. Treatment of severe acute graft-versus-host disease with third party haploidentical mesenchymal stem cells. Lancet. 2004:363:1439_ 41. https://doi.org/10.1016/S0140-6736(04)16104-7. 